\title{
Aplikasi Pembatasan Area Virtual (Geofence) Untuk Pemantauan Aktifitas Anak-Anak Menggunakan Smartphone dan Smartwatch
}

\author{
I Nyoman Eddy Indrayana ${ }^{1}$, I Putu Sutawinaya ${ }^{2}$, Ni Made Wirasyanti Dwi Pratiwi ${ }^{3}$, Kadek Amerta Yasa ${ }^{4}$ \\ 1,2,4 Teknik Elektro, Politeknik Negeri Bali \\ ${ }^{3}$ Akuntansi, Politeknik Negeri Bali \\ 1'eddyindrayana@pnb.ac.id, ${ }^{2}$ sutawinaya_putu@pnb.ac.id, ${ }^{3}$ madewirasyantidwipratiwi@pnb.ac.id, ${ }^{4}$ amerta.yasa@pnb.ac.id
}

\begin{abstract}
Monitoring the movement of children is needed by parents to avoid things that are not desirable. GPS technology can be used to carry out surveillance via cellphones combined with virtual area restrictions (geofence) to increase supervision when parents are not near their children. This virtual area limitation will help provide automatic signals to parents when children move outside the permitted area. This application is built using the Unified System Development Process (USDP) method and applies the Haversine formula to calculate the distance between two positions on earth. The Haversine formula is used in the process of detecting whether an object is in the permitted area or not. The virtual area limitation in this application uses a circle shape. This application requires two actors, namely the parent actor who acts as a monitor and the child actor who acts as the object being monitored. Parents use Android phones to see children's movements via Google Maps and at the same time to manage the child's geofences so that monitoring is easier. Meanwhile, the child uses a smartwatch to send the latitude and longitude coordinates of his position to the firebase database server. The smartwatch device used by the child is lighter and more practical because it is worn on the hand.
\end{abstract}

Keywords: geofence, haversine formula, children's monitoring application

\begin{abstract}
Abstrak
Pemantauan pergerakan anak-anak sangat dibutuhkan oleh orang tua untuk menghindari hal hal yang tidak diinginkan. Teknologi GPS dapat dimanfaatkan untuk melakukan pengawasan melalui smartphone yang dikombinasikan dengan pembatasan area secara virtual(geofence) untuk meningkatkan pengawasan pada saat orang tua tidak berada di dekat anakanaknya. Pembatasan area secara virtual ini akan membantu memberikan sinyal otomatis kepada orang tua pada saat anak-anak melakukan pergerakan diluar area yang diijinkan. Aplikasi ini dibangun menggunakan metode Unified System Development Process(USDP) dan menerapkan rumus Haversine untuk menghitung jarak antara 2 posisi di bumi. Rumus Haversine ini digunakan dalam proses mendeteksi apakah suatu objek berada pada area yang diijinkan ataukah tidak. Pembatasan area virtual dalam aplikasi ini menggunakan bentuk lingkaran. Aplikasi ini membutuhkan 2 aktor yaitu aktor orang tua yang bertindak sebagai pemantau dan aktor anak yang bertindak sebagai objek yang dipantau. Orang tua menggunakan smartphone android untuk melihat pergerakan anak melalui google map dan sekaligus untuk mengatur geofence si anak sehingga lebih mudah melakukan pemantauan. Sedangkan si anak menggunakan smartwatch untuk mengirimkan koordinat latitude dan longitude posisinya ke server database firebase. Perangkat smartwatch yang digunakan si anak ini, lebih ringan dan lebih praktis karena dipakai di tangan.
\end{abstract}

Kata kunci: geofence, rumus haversine, aplikasi pemantauan anak-anak.

\section{Pendahuluan}

Dewasa ini, orang tua sangat sibuk dengan rutinitas mereka dalam menghidupi kelurganya [1]. Sering kali orang tua tidak memiliki waktu untuk memantau Kini, teknologi GPS hadir di tengah-tengah kita untuk pergerakan anak-anaknya karena sibuk dengan membantu menentukan posisi suatu benda di bumi [4,5]. pekerjaan di kantor atau urusan mereka sendiri [2]. Teknologi GPS [6] ini dapat digabungkan dengan Sedangkan anak anak sering kali lupa pada saat bermain pembatasan virtual (geofence) untuk membatasi terlebih lagi diluar jam sekolah sehingga orang tua pergerakan suatu objek di suatu area tertentu [7]. Untuk sering kehilangan posisi anak pada saat melakukan mendapatkan posisi lintang dan bujur GPS, diperlukan aktivitas di luar ruangan [3]. Orang tua sering perangkat keras penerima sinyal GPS. Penerima GPS mengkhawatirkan keselamatan anak-anak mereka, memerlukan minimal 3 sinyal satelit GPS [8] untuk sementara orang tua tidak ada untuk anak-anak mereka. mendapatkan koordinat garis lintang dan bujur yang Orang tua seringkali khawatir dengan keselamatan akurat. Jika sinyal satelit terhalang oleh gedung-gedung anaknya, sedangkan orang tua tidak berada di samping tinggi, gunung atau pepohonan, akurasi posisi koordinat anaknya.

Orang tua menginginkan sistem yang dapat memantau posisi anak-anak mereka dan dapat membatasi pergerakan anak-anak mereka. Orang tua ingin mendapatkan notifikasi jika anak beraktivitas di luar area yang tidak diizinkan. Ini untuk mengurangi kejadian yang tidak diinginkan dari orang tua, terhadap anak-anaknya

akan berkurang. Sekarang penerima sinyal GPS semakin kecil ukurannya, dan sekarang tertanam dengan perangkat keras lain, seperti ponsel pintar dan jam tangan pintar. 
Teknologi GPS ini dapat digabungkan dengan sekolah. Pada penelitian Sunehra dibuat modul transmisi pembatasan virtual (geofence) untuk membatasi data anak dengan mikrokontroler ARM7 LPC2148 yang pergerakan suatu objek di suatu area tertentu [9]. dihubungkan ke beberapa modul diantaranya modul Pemanfaatan koordinat GPS dapat digunakan pada batas penerima GPS, modul GSM dan modul catu daya. Posisi virtual (geofence) dengan mengatur batas virtual terlebih latitude dan longitude anak dikirimkan secara berkala dahulu. Areal yang cukup lumayan ini menjadi patokan melalui perangkat yang digunakan oleh anak, ke bagi anak-anak untuk beraktivitas. Sistem dibuat untuk smartphone orang tua melalui pesan SMS. Smartphone mendeteksi apakah posisi anak masih berada di dalam orang tua dapat melihat posisi anaknya di google map kawasan yang diizinkan, atau berada di luar batas sesuai dengan data posisi yang telah dikirimkan. Dalam kawasan aman. Notifikasi akan diberikan kepada orang penelitian Sunehra, perangkat keras untuk transmisi tua jika anaknya melakukan aktivitas di luar geofence.

Segara dan Subari membuat aplikasi pemantauan anak dengan geofence [1]. Aplikasi ini dibuat dengan 2 sistem. Pihak orang tua menggunakan aplikasi berbasis web dan pihak anak-anak menggunakan aplikasi android yang diinstalasi pada smartphone. Aplikasi android si anak difungsikan untuk mendaftarkan perangkat baru dan data si anak ke sistem. Disamping itu smartphone anak digunakan untuk mengirimkan posisi dari si anak ke server setelah berhasl login ke sistem. Orang tua dapat melihat posisi anak-anak secara realtime melalui aplikasi web yang dilengkapi dengan google map. Orang tua juga dapat mengatur geofence melalui aplikasi berbasis web ini. Jika si anak melakuakn aktifitas di luar geofence yang sudah ditetapkan, maka aplikasi orang tua akan memberikan notifikasi bahwa si anak berada diluar area yang diijinkan.

Penelitian yang dibuat oleh Karthikeyan juga posisi anak masih memiliki ukuran yang relatif besar sehingga perlu dipikirkan untuk menggunakan alat yang memiliki dimensi lebih kecil dan cara mengirimkan data posisi masih menggunakan SMS(Short Message Service)

Aditi Gupta membangun aplikasi untuk melacak lokasi anak dan mengirimkan pesan berupa SMS ke orang tua jika anak berada dalam keadaaan darurat [12]. Model arsitektur tujuan Aditi Gupta untuk keselamatan anak melalui smartphone yang menyediakan fitur untuk melacak lokasi anak dan mengirim pesan pendek [12], jika anak tersebut dalam keadaan darurat. Model arsitektur sistem yang diusulkan adalah dilengkapi dengan fasilitas geofence. Sistem akan mengirimkan file SMS sebagai pemberitahuan, jika anak-anak melewati batas virtual yang sudah di set sebelumnya. Orang tua bisa mengatur lebih dari satu geofence setiap saat sesuai dengan keperluan mereka.

menggunakan geofence untuk memantau dan melacak Pada penelitian ini dilakukan pembuatan program untuk penyedia jasa pengasuh bayi di sekitar pengguna sistem pembatasan area virtual untuk anak-anak dengan [10]. Apikasi ini diperuntukkan kepada orang tua yang menggunakan smartwatch dari pihak pengguna anakmemiliki sedikit waktu untuk mengurus pekerjaan di anak dan menggunakan smartphone dari pihak pengguna rumah, karena sibuk dengan pekerjaan kantor. Pengguna orang tua. Penggunaan smartwatch lebih fleksible dan aplikasi bisa menjadi pelanggan dan bisa juga menjadi lebih ringan untuk anak-anak.

penyedia layanan. Aplikasi ini juga menyediakan layanan seperti perawatan bayi, perawatan pasien, perawatan di rumah, perawatan anak yatim dan layanan berbagi lokasi.

\section{Metode Penelitian}

Penelitian ini menggunakan metode pengembangan rekayasa perangkat lunak Unified Software Penelitian yang dilakukan oleh Beny yaitu membuat Development Process (USDP) [13]. USDP merupakan aplikasi geofence untuk membatasi pergerakan anak [2]. metodologi untuk pengembangan perangkat lunak, Aplikasi ini membutuhkan minimum 2 perangkat khususnya perangkat lunak berorientasi objek. Metode smartphone. Satu smartphone digunakan oleh pihak ini diawali dengan pembuatan use case, yang pada orang tua untuk mendaftarkan data anak yang akan prinsipnya mendapatkan spesifikasi kebutuhan dipantau, melakukan pengaturan geofence dan pengguna. Metode USDP memiliki 4 tahapan kerja, digunakan untuk melihat posisi anak melalui google yaitu

map. Smartphone lainnya digunakan oleh si anak untuk mengirimkan posisi latitude dan longitude ke server. Dari segi flesibelitas dan mobilitas Penggunaan smartphone relatif lebih "merepotkan" untuk anak, terlebih tingkat kontrol anak yang rendah, smartphone memerlukan space untuk penyimpanan atau membawa sehingga sering kali anak teledor, terlupakan yang mengakibatkan perangkat tersebut hilang, ataupun tertinggal.

Dhiraj Sunehra membuat alat yang digunakan orang tua untuk memantau posisi anak-anak di sekolah [11]. Alat ini juga terhubung dengan otoritas sekolah sehingga sekolah juga dapat memantau pergerakan anak selama di

Inception, merupakan tahapan pembuatan perangkat lunak dengan melakukan wawancara kepada pihak pengguna. Tahap ini dilakukan identifikasi terhadap kebutuhan kebutuhan aplikasi yang akan dibangun. Dilakukan pengumpulan data terhadap input dan output sistem sehingga diharapkan terjadi penyamaan persepsi antara keinginan pengguna dengan pembuat aplikasi.

Elaboration, merupakan tahapan lanjutan setelah inception. Data yang diperoleh dari tahapan inception ditransformasikan ke dalam diagram diagram sebagai persiapan untuk programer membuat code ke dalam bahasa pemrograman tertentu. Pendekatan perangkat lunak berbasis objek dapat menggunaan diagram Use 
Case. Diagram Use Case digunakan untuk 3. Hasil dan Pembahasan menggambarkan sistem secara fungsional. Diagram Use Case terdiri dari beberapa elemen dasar yaitu Aktor,

\subsection{Usulan Desain Sistem}

pembatas sistem (boundary system), use case, dan relasi Pada Tahap Inception penelitian ini , dilakukan antar use case. Aktor dapat berupa orang, profesi, pengumpulan data input dan wawancara ke penguna institusi, perangkat keras, atau sistem lain yang berperan aplikasi. Dari pengumpulan data awal dibutuhkan 2 dalam berinteraksi dengan sistem. Suatu use case di aktor sebagai pengguna sistem yaitu orang tua dan anak. stimulus minimal oleh seorang aktor, dan antar case Aktor orang tua dan anak memiliki peranan masingdapat mempunyai hubungan dalam bentuk "extends" masing dalam sistem. Dalam aplikasi ini, aktor anakatau "include". Extends mengandung pengertian anak merupakan objek yang dipantau oleh aktor orang perluasan dari suatu case menjadi case yang lain jika tua. Aplikasi pembatasan area secara virtul ini kondisi atau ketentuan terpenuhi. Use case perluasan membutuhkan data primer seperti data posisi anak, data tersebut dapat dilaksanakan atau dapat juga tidak keluarga, data batas geofence, dan data orang tua. Pada dilaksanakan. Sedangkan hubungan include aplikasi ini membutuhkan smartphone dan smartwatch mengandung pengertian use case yang ditambahkan untuk komunikasi antara orang tua dan anak-anak. harus dilaksanakan jka use case yang dihubungkan tadi Smartphone digunakan oleh orang tua sedangkan dilakukan.

smartwatch digunakan oleh anak-anak.

Construction, merupakan tahapan dimana diagram Aktor anak-anak menggunakan perangkat smartwatch diagram yang sudah dibuat di tahapan elaborasi yang dilengkapi perangkat GPS. Aplikasi pada smart diterjemahkan ke dalam bahasa pemrograman tertentu watch, akan mengirimkan posisi anak-anak ke database untuk membangun user interface yang sesuai dengan Firebase melalui jaringan internet. Para orang tua, keinginan pengguna. Tentunya pada tahapan ini melalui smartphone mereka, akan mengambil data dari kesalahan-kesalahan coding harus diperbaiki, supaya database Firebase, yang kemudian menampilkan posisi aplikasi yang dibuat dapat terwujud sesuai dengan anak-anak di peta google. Orang tua juga dapat membuat rancangan awal.

pengaturan geofence melalui perangkat smartphone

Transition, merupakan tahapan dimana aplikasi diterapkan pada pengguna. Hal hal yang diperlukan dalam penyempurnaan aplikasi dan pengujian sesuai dengan lingkungan sesunguhnya dilakukan dalam tahap ini. mereka. Notifikasi diberikan kepada orang tua melalui perangkat smartphone jika anak-anak berada di luar area yang diizinkan.

Sistem dirancang secara fungsional untuk memiliki beberapa fasilitas seperti berikut: (1)Anak-anak dapat Dalam metode USDP terdapat iterasi di setiap tahapn mengirimkan posisi mereka secara real-time ke server. yang sudah diuraikan diatas. Iterasi yang dilakukan yaitu (2)Orang tua dapat melihat semua nama anggota tahapan persyaratan, analisis, desain, implementasi, dan keluarga mereka. (3)Orang tua dapat melihat semua pengujian.

Dalam pembuatan aplikasi menggunakan pembatas virtual(geofence) ini digunakan satu rumus untuk menghitung jarak antara 2 posisi(point) di bumi. Rumus yang digunakan adalah rumus haversine $[14,15]$. Rumus ini cocok untuk membuat pembatas virtual dalam bentuk lingkaran. Adapun rumus haversine [16,17] tersebut adalah:

$$
\begin{aligned}
\operatorname{Haversine}\left(\frac{d}{r}\right)= & \text { haversine }\left(\emptyset_{2}-\emptyset_{1}\right) \\
& +\cos \left(\emptyset_{1}\right) \cos \left(\emptyset_{2}\right) \text { haversine }\left(\lambda_{2}\right. \\
& \left.-\lambda_{1}\right)
\end{aligned}
$$
posisi anak secara real-time di peta google. (4)Orang tua dapat menetapkan pembatasan wilayah untuk setiap anak. (5)Orang tua dapat menerima pemberitahuan jika anak-anak melewati batas pembatasan wilayah yang telah ditentukan.

Aplikasi ini dibuat dengan menggunakan Android Studio dan Google API untuk menampilkan peta google. Database firebase digunakan untuk menyimpan data sistem secara real-time.

Pada tahap elaboration, dilakukan pembuatan use case diagram dari data data yang di peroleh pada tahap inception.

dimana : Haversine $(\mathrm{x})=1-\cos (\mathrm{x}) / 2, \mathrm{~d}$ adalah jarak antara dua titik, $\mathrm{r}$ adalah jari-jari bola, $\varnothing_{-} 1, \emptyset_{\_} 2$ adalah garis lintang titik1 dan garis lintang titik $2 . \lambda \_1, \lambda \_2$ adalah bujur titik 1 dan bujur titik 2 . 
Use Case Aplikasi Pembatasan Virtual Anak Anak

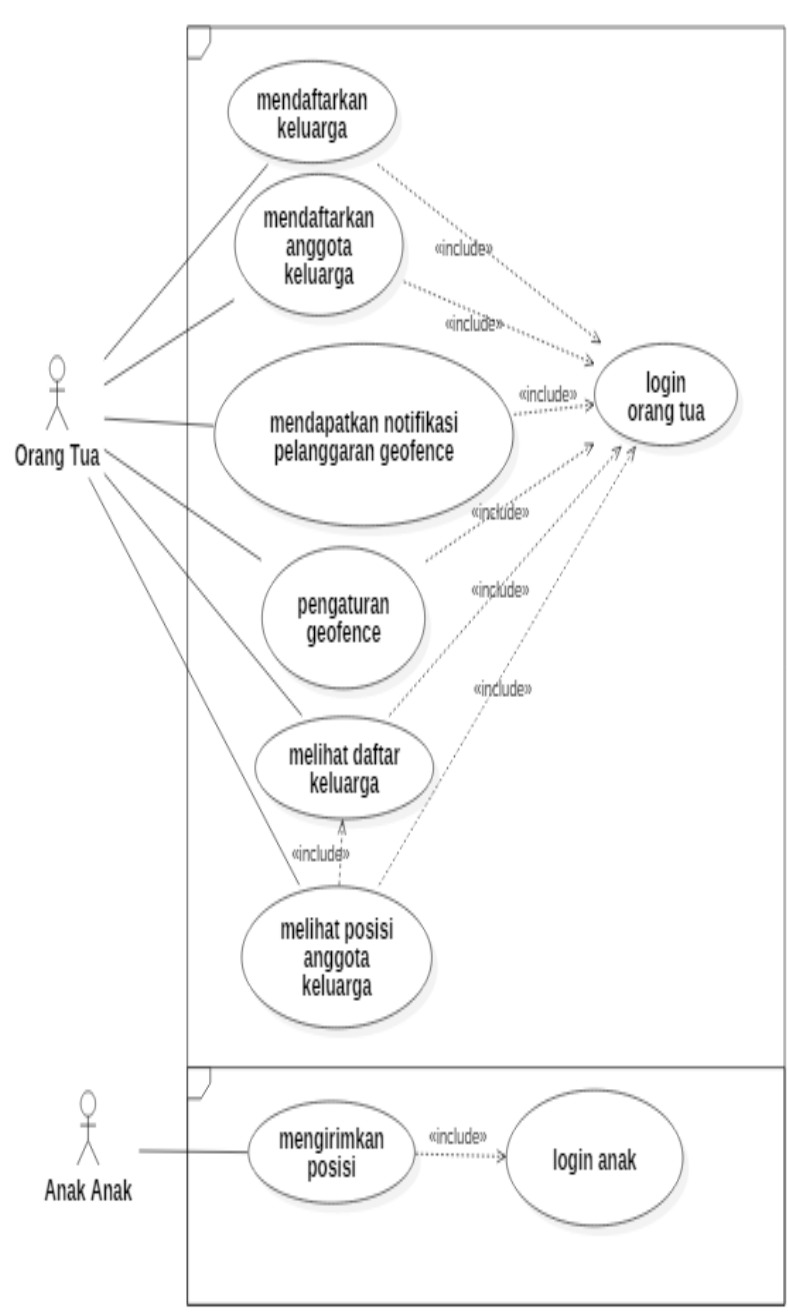

Gambar 1. Use Case Diagram Aplikasi Pembatasan Area Virtual Anak-Anak

Pada gambar 1, Use case "mendaftarkan keluarga", digunakan oleh aktor orang tua untuk untuk mendaftarkan nama keluarga melalui aplikasi mobile. Data-data keluarga yang didaftarkan diantaranya id kepala keluarga, nama keluarga, nama kepala keluarga, alamat keluarga, dan kata sandi. Sebagai identifikasi digunakan email kepala keluarga. Use case "mendaftarkan anggota keluarga", dilakukan oleh aktor orang tua untuk mendaftarkan nama anggota keluarga. Use case ini digunakan untuk mendaftarkan data anak. Data anak seperti nomor kartu seluler anak, nama anak, nama panggilan, dan tanggal lahir. Use case "mendapatkan notifikasi pelanggaran geofence" digunakan oleh aktor orang tua untuk mendapatkan sinyal atau tanda dari aplikasi, jika ada salah satu dari anggota keluarga melakukan pergerakan keluar dari geofence yang sudah ditetapkan sebelumnya. Use case "pengaturan geofence" digunakan oleh aktor orang tua untuk mengatur area yang diperbolehkan anak - anak melakukan aktifitas pada tanggal tertentu. Use case "melihat daftar keluarga" dilakukan oleh aktor orang tua, untuk melihat semua anggota keluarga yang terdaftar di aplikasi. Fasilitas ini untuk memudahkan para orang tua mengetahui siapa di antara anaknya yang belum atau siapa yang sudah terdaftar. Daftar ini dapat digunakan sebagai media untuk membantu memilih posisi anaknya di google map. Use case "melihat posisi anggota keluarga", dilakukan oleh orang tua pelaku untuk melihat posisi anak di google map. Orang tua bisa melihat posisi anak yang dipilih melalui daftar di layar smartphone android. Posisi anak akan bergerak secara real-time, sesuai dengan pergerakan anak. Semua use case yang sudah disebutkan di atas, terlabih dahulu melakukan use case "login orang tua" untuk melakukan proses validasi bahwa aktor orang tua yang login memiliki hak akses ke dalam aplikasi.

Aktor anak anak dapat melakukan use case "login anakanak" dan use case "mengirimkan posisi". Use case "mengirimkan posisi" dilakukan oleh aktor anak-anak, dimana anak-anak terlebih dahulu melakukan use case "login anak". Hanya username dan password yang terdaftar di database yang boleh masuk ke aplikasi. Setelah valid, anak-anak dapat mengirim posisi lintang dan bujur mereka melalui perangkat smart watch yang mana data posisi anak-anak ini akan disimpan ke dalam database firebase.

\subsection{Pengaturan Geofence}

Aplikasi ini dibangun dengan menerapkan pembatasan area virtual dalam bentuk area lingkaran. Area lingkaran ini sebagai batas wilayah yang boleh dilalui atau ditempati anak-anak selama melakukan aktivitas. Area virtual lingkaran ini akan disimpan dalam bentuk dua titik yaitu posisi titik pusat lingkaran dan titik terluar yang diijinkan. Sehingga kita perlu menghitung jarak anatar dua titik di bumi dengan menggunakan rumus haversine. Rumus haversine ini akan menghitung jarak menghitung jarak antara posisi lintang dan bujur si anak dengan titik pusat geofence. Jarak ini kita sebut sebagai jarak maksimum. Kemudian kita menghitung jarak posisi anak dengan titik tengah geofence yang kita sebut jarak anak. Jika jarak anak lebih besar dari jarak maksimal maka posisi anak berada di luar area yang diperbolehkan.

Untuk implementasi pada source code java android studio perhitungan jarak menggunakan rumus haversine dapat dilihat berikut ini:

Method untuk menghitung jarak(rumus haversine)

public static double getDistanceFromLatLngInMeter (double 1at1, double 1on1, double lat2, double lon2) final int $\mathrm{R}=6371$; // Radius of the earth

double 1atDistance $=$

Math. toRadians (Math.abs (1at2 - 1at1)); double 1onDistance $=$

Math. toradians (Math.abs(1on2 - 1on1));

double $a=$ Math.sin(1atDistance / 2) *

Math.sin(1atDistance / 2)

+ Math. cos (Math.toRadians (1at1))

* Math. cos(Math. toradians (1at2))

* Math.sin(1onDistance / 2) 
* Math.sin(1ondistance / 2);

double $c=2 *$ Math.atan2 (Math.sqrt(a), Math.sqrt $(1-a))$; double distance $=\mathrm{R} * \mathrm{c} * 1000 ; / /$ distance in meter

distance = Math. pow (distance, 2); \} return Math.sqrt(distance);

\section{pub7ic static double}

getDistanceFromLatLonInKm (1ong 1at1, 1ong lon1, 1ong 1at2, long 1on2) \{

in $\mathrm{km}$ double $\mathrm{R}=6371 \mathrm{D} ; / /$ Radius of the earth

double dLat $=\operatorname{deg} 2 \operatorname{rad}(1 a t 2-1 a t 1)$; deg2 rad below

double dLon = deg $2 \operatorname{rad}(10 n 2-$ 1on 1$)$;

double $\mathrm{a}=$

(2) +

Math.sin(dLat / 2) * Math.sin(dLat

Math. $\cos (\operatorname{deg} 2 \operatorname{rad}(1 \mathrm{at} 2))$ : Math. $\cos (\operatorname{deg} 2 \operatorname{rad}(1 a t 1)) *$

* Math.sin(dLon / 2);

Math.sin(dLon / 2)

double $\mathrm{c}=2 *$ Math. atan2(Math.sqrt (a), Math.sqrt $(1-a))$;

Log. e(Constant. TAG,

"getDistanceFromLatLonInKm: " + c); \}

return $\mathrm{R} * \mathrm{C}$;

\subsection{Pengujian Aplikasi}

Implementasi dari penelitian ini menggunakan database firebase. Sehingga harus dipastikan perangkat yang kita pakai minimum menggunakan target API level 16 (Jelly Bean) atau yang lebih tinggi dan menggunakan Gradle 4.1 atau yang lebih baru. Smart watch yang digunakan dalam pengujian ada 2 type . Type 1 smartwatch Q1 Pro dengan sistem operasi Android 6.0, CPU: MTK6737 Quad Core, $1.3 \mathrm{GHz}$ yang tampilannya dapat dilihat pada gambar 3. Type 2 smartwatch All Call W2 3G dengan sistem operasi Android 7.0, CPU : MTK6580 Quad Core, $1.3 \mathrm{GHz}$ yang tampilannya dapat dilihat pada gambar 4. Dari dua type smartwatch yang dilakukan pengujian ini, aplikasi dapat berjalan secara normal. Aplikasi ini juga diimplementasikan menggunakan fasilitas dari google map untuk melihat posisi dan pergerakan anak. Untuk menggunakan Maps JavaScript API, kita harus memiliki kunci API. Kunci API adalah kunci unik yang digunakan untuk mengautentikasi permintaan yang terkait dengan aplikasi yang kita buat dalam hal penggunaan peta sumber daya dari google. Berikut beberapa tampilan aplikasi yang telah dibangun:

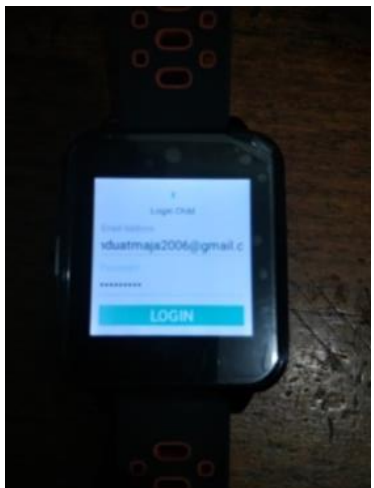

Gambar 2. Tampilan Login Pada Smartwatch Q1 Pro

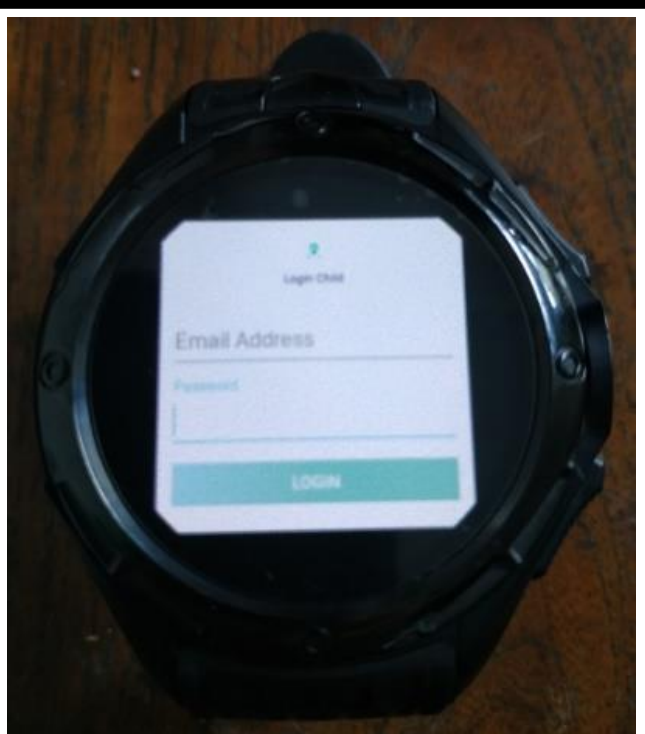

Gambar 3. Tampilan Login Pada Smartwatch All Call W2
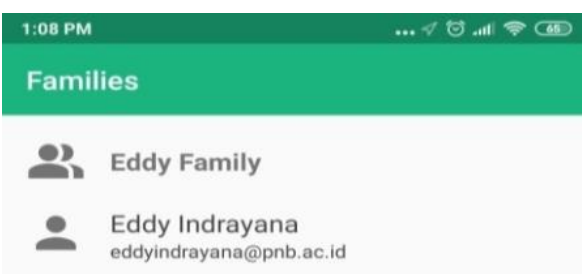

Pandu Atmaja

Email: panduatmaja2006@gmail.com : Child

Eddy Indrayana

Email: eddyindrayana@pnb.ac.id

Parent

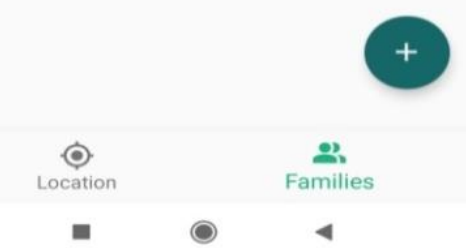

Gambar 4. Tampilan Daftar Keluarga

Pada gambar 4 , merupakan tampilan dari daftar anggota dari suatu keluarga dengan seorang ayah. Dari user interface ini orang tua dapat melihat semua anak yang sudah terdaftar. Gambar 5 adalah tampilan posisi anak pada google map. Semua anak yang terdaftar menggunaan smartwatch akan terlihatdi google map. Sedangkan tampilan pada gambar 6 adalah tampilan pengaturan geofence dari si anak. Pengaturan geofence dapat dilakukan dari tanggal sampai tanggal tertentu dan dapat diatur radiusnya. 


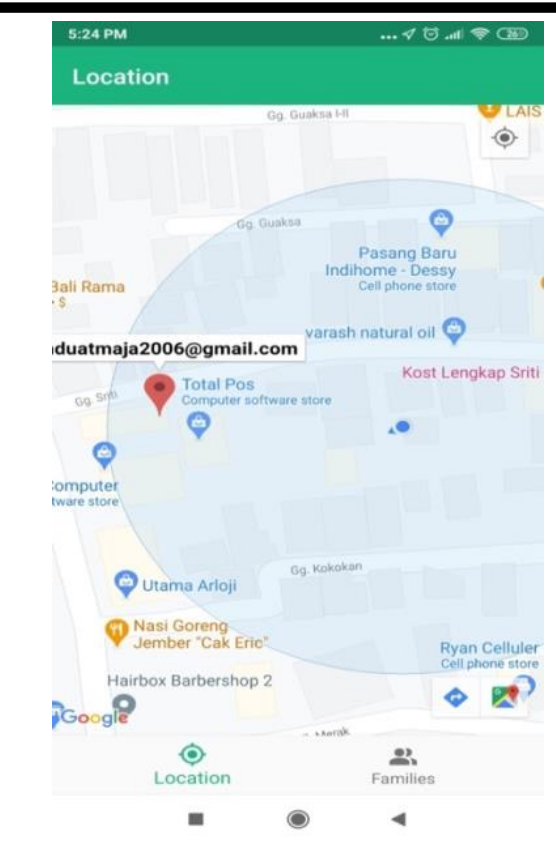

Gambar 5. Tampilan Posisi Anak Pada Google Map

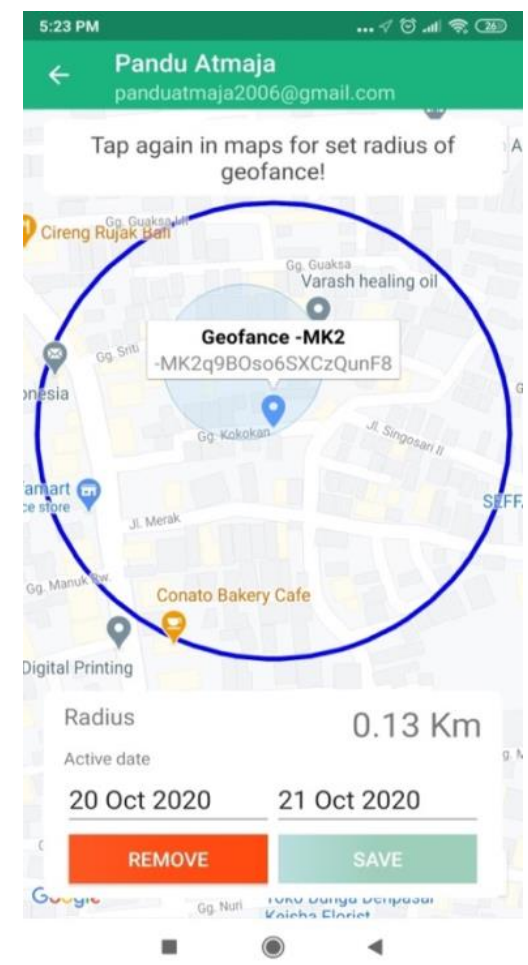

Gambar 6. Tampilan Pengaturan Geofence

\section{Kesimpulan}

Adapun kesimpulan dari penelitian ini adalah pembatasan area secara virtual dapat diterapkan menggunakan smartphone dan smartwatch dengan sistem operasi Android. Aktor yang terlibat dalam aplikasi pembatasan area virtual ini yaitu aktor orang tua dan aktor anak. Rumus haversine dapat diterapkan pada geofence berbentuk lingkaran untuk mendeteksi apakah suatu posisi berada di area yang diijinkan ataukah berada di area yang tidak diijinkan. Penggunaan smartwatch lebih fleksible dan lebih ringan untuk anak-anak yang memiliki mobilitas yang relatif tinggi.

\section{Ucapan Terimakasih}

Ucapan terima kasih kepada Direktorat Riset dan Pengabdian Masyarakat, Kementrian Riset dan Teknologi / Badan Riset dan Inovasi Nasional yang telah membiayai penelitan ini, sesuai dengan Amandemen Kontrak Penelitian No.133/SPH/AMD/LT/DRPM/2020 SP DIPA-042.06.1.401516/2020 tanggal 12 November 2019 dan Kontrak Penelitian No. 802/PL8/AMD/LT/2020.

\section{Daftar Rujukan}

[1] Segara, R. and Subari, S., 2017, Sistem Pemantauan Lokasi Anak Menggunakan Metode Geofencing Pada Platform Android, Jurnal Teknologi dan Manajemen Informatika, vol. 3, no. 1, doi: 10.26905/jtmi.v3i1.629.

[2] Beny, Budiman, J., and Nugroho, A., 2017, Implementasi Geofencing Pada Aplikasi Layanan Pemantau Anak Berbasis Lokasi, in 2nd Seminar Nasional IPTEK Terapan (SENIT), pp. 63-66.

[3] Indrayana, I. N. E., Sutawinaya, P., Wirasyanti, N. M., Swardika, I. K., and Sunu, P. W., 2020, Design of Children Monitoring Application for Outdoor Activities Using a Smart Watch, in Journal of Physics: Conference Series, vol. 1569, p. 32093, doi: 10.1088/1742-6596/1569/3/032093.

[4] Sudiartha, I. K. G., Indrayana, I. N. E., Suasnawa, I. W., and Ciptayani, P. I., 2018, Design And Implementation of Group Tourist Monitoring Application With Realtime Database Firebase, in International Conference on Science and Technology (ICST 2018), Dec. 2018, pp. 1078-1083, doi: https://doi.org/10.2991/icst-18.2018.217.

[5] Sudiartha, I. K. G., Indrayana, I. N. E., Suasnawa, I. W., Asri, S. A., and Sunu, P. W., 2020, Data Structure Comparison between MySql Relational Database and Firebase Database NoSql on Mobile Based Tourist Tracking Application, Journal of Physics: Conference Series, vol. 1569, no. 3, doi: 10.1088/17426596/1569/3/032092.

[6] Rahate, S. and Shaikh, M., 2016, Geo-fencing Infrastructure: Location Based Service, International Research Journal of Engineering and Technology, vol. 03, no. 11, pp. 1095-1098.

[7] Bohli, J. M., Dobre, D., Karame, G. O., and Li, W., 2014, PrivLoc: Preventing location tracking in Geofencing services, in International Conference on Trust and Trustworthy Computing, , vol. 8564, April 2014, pp. 143-160, doi: 10.1007/978-3-31908593-7_10.

[8] Daniel, L. E. and Daniel, L. E., 2012, Global Positioning Systems, in Digital Forensics for Legal Professionals, L. E. Daniel and L. E. B. T.-D. F. for L. P. Daniel, Eds. Boston: Elsevier, pp. 309-319.

[9] Priyanka Mohite, Adarsh Nair, N. S., 2016, Geofencing and Locatoin Based Reminder Services, International Journal of Advance Engineering and Research Development, vol. 3, no. 10, pp. 137-141, doi: 10.21090/ijaerd.031025.

[10]Karthikeyan, B., Charan, R., Ganapathy, L., Gobuviknesh, J., and Afsal, P., 2017, Self-Care Application Using Android Google Maps and Geofence, International Journal of Computer Science Trends and Technology, vol. 5, no. 2, pp. 28-32.

[11]Sunehra, D., Priya, P. L., and Bano, A., 2016, Children Location Monitoring on Google Maps Using GPS and GSM Technologies, in 2016 IEEE 6th International Conference on Advanced Computing (IACC), Feb. 2016, pp. 711-715, doi: 10.1109/IACC.2016.137.

[12]Gupta, A. and Harit, V., 2016, Child Safety \& Tracking Management System by Using GPS, Geo-Fencing \& Android Application: An Analysis, in 2016 Second International Conference on Computational Intelligence \& Communication Technology (CICT), Feb. 2016, pp. 683-686, doi: 10.1109/CICT.2016.141. 
[13]Wang, Z., 2011, The study of smart phone development based on UML, 2011 International Conference on Computer Science and Service System, CSSS 2011 - Proceedings, pp. 2791-2794, doi: 10.1109/CSSS.2011.5973939.

[14]Dauni, P., Firdaus, M. D., Asfariani, R., Saputra, M. I. N., Hidayat, A. A., and Zulfikar, W. B., 2019, Implementation of Haversine formula for school location tracking, Journal of Physics: Conference Series, vol. 1402, no. 7, doi: 10.1088/1742$6596 / 1402 / 7 / 077028$.

[15]Ganesh and Kumar, V., 2015, Indoor Wireless Localization using Haversine Formula, Iarjset, vol. 2, no. 7, pp. 59-63, doi: 10.17148/IARJSET.2015.2713

[16]Hartanto, S., Furqan, M., Putera, A., Siahaan, U., and Fitriani, W., 2017, Haversine Method in Looking for the Nearest Masjid, International Journal of Recent Trends in Engineering and Research, vol. 3, no. 8, pp. 187-195, doi: 10.23883/ijrter.2017.3402.pd61h.

[17]Alsaqer, M., Hilton, B., Horan, T., and Aboulola, O., 2015, Performance Assessment of Geo-triggering in Small Geo-fences: Accuracy, Reliability, and Battery Drain in Different Tracking Profiles and Trigger Directions, Procedia Engineering, vol. 107, pp. 337-348, doi: 10.1016/j.proeng.2015.06.090. 